WIDER Working Paper 2014/128

Local agency, development assistance and the legacies of rebellion in Burundi and Rwanda

Devon E. A. Curtis*

October 2014 
Abstract: Rwanda and Burundi have both emerged from civil wars over the past 20 years and foreign donors have provided significant contributions to post-conflict reconstruction and development in the two countries. Yet although Rwanda and Burundi share several important characteristics, the social, political and economic trajectories of the two countries have been different. The paper argues that the nature of the ruling parties in Rwanda and Burundi is key to understanding the countries' relationships with donors. Rather than seeing aid as an exogenous factor causing particular development outcomes, the paper shows how local party elites exert considerable agency over the aid relationship. Their agency, however, is influenced and constrained by a number of different local contextual factors, including pre-civil war structures. Thus, the paper provides an analysis of how local context matters in understanding donorrecipient aid relationships, and how the ruling party in Rwanda (the RPF) and in Burundi (the CNDD-FDD) emerged from their respective conflicts with different relationships with international donors.

Keywords: Rwanda, Burundi, development assistance, rebel movement transitions, local agency JEL classification: O19, O29, Z19

Acknowledgements: The author thanks Rachel Gisselquist for her very helpful comments on the first draft of this paper, as well as the participants in a UNU-WIDER workshop held in Helsinki in November 2013.

\footnotetext{
* University of Cambridge; dc403@cam.ac.uk

This study has been prepared within the UNU-WIDER project 'ReCom-Foreign Aid: Research and Communication', directed by Tony Addison and Finn Tarp.

Copyright (C) UNU-WIDER 2014

ISSN 1798-7237 ISBN 978-92-9230-849-0

Typescript prepared by Janis Vehmaan-Kreula at UNU-WIDER.

UNU-WIDER gratefully acknowledges specific programme contributions from the governments of Denmark (Ministry of Foreign Affairs, Danida) and Sweden (Swedish International Development Cooperation Agency-Sida) for ReCom. UNUWIDER also gratefully acknowledges core financial support to its work programme from the governments of Denmark, Finland, Sweden and the United Kingdom.
}

The World Institute for Development Economics Research (WIDER) was established by the United Nations University (UNU) as its first research and training centre and started work in Helsinki, Finland in 1985. The Institute undertakes applied research and policy analysis on structural changes affecting the developing and transitional economies, provides a forum for the advocacy of policies leading to robust, equitable and environmentally sustainable growth, and promotes capacity strengthening and training in the field of economic and social policy-making. Work is carried out by staff researchers and visiting scholars in Helsinki and through networks of collaborating scholars and institutions around the world.

UNU-WIDER, Katajanokanlaituri 6 B, 00160 Helsinki, Finland, wider.unu.edu

The views expressed in this publication are those of the author(s). Publication does not imply endorsement by the Institute or the United Nations University, nor by the programme/project sponsors, of any of the views expressed. 
It has long been acknowledged that the effects of Overseas Development Assistance (ODA) are contingent upon the domestic context of recipient countries. ${ }^{1}$ Thus, understanding development outcomes cannot be limited to analyses of the volume of aid, the type of aid, and the identity of the donors, but must also consider the relationship between aid and political, economic and social structures in the recipient country. Likewise, in seeking to explain the relationship between aid donors and recipients, a number of scholars have argued that well-established international relations and development theories have underestimated the role of local agency, meaning the agency of elites and other actors in aid-recipient countries. While local agents certainly face structural constraints, there is a large and diverse literature, particularly in African politics and development, which focuses on how African agents exert their influence in the international and domestic spheres. ${ }^{2}$

Yet even though there is some agreement in the literature on the importance of local political context and local agency in understanding donor-recipient aid relationships, there is no consensus on precisely how they matter. This paper focuses on international donor relations with Rwanda and Burundi, two countries that share important social, political and economic characteristics, but with different relationships with international donors. An analysis of Rwanda and Burundi's different trajectories highlights how national elites influence aid relationships, but also how these elites are shaped by particular historical structures and processes.

Rwanda and Burundi have been called false twins, due to their similar ethnic cleavages, colonial histories and experiences of political violence. 3 The two countries were not artificial creations of colonial rule, and by the time they were absorbed into German East Africa in 1898-99, most of the territory had already been incorporated into two kingdoms. The two countries have similar ethnic divisions, with a Tutsi minority and Hutu majority and a much smaller third group, the Twa. ${ }^{4}$ Nonetheless, there are important differences as well (hence the name false twins). Perhaps most notably, the majority Hutu dominated the post-colonial political, economic and military landscape until the 1990s in Rwanda, whereas in Burundi it was the minority Tutsi that dominated until the early 1990s.

The countries share a history of violence and conflict, often expressed ethnically, including genocidal killings in Burundi in 1972 and in Rwanda in 1994. There was civil war in Rwanda between 1990-94 and in Burundi from 1993. Civil war ended in Rwanda with the Rwandan Patriotic Front's (RPF) military victory in 1994, whereas Burundi's civil war largely ended in 2005 with democratic elections following prolonged negotiations involving regional and international actors. The former Burundian rebels, the National Council for the Defense of DemocracyForces for the Defense of Democracy (CNDD-FDD) won the elections. 5 Thus, the current

1 For an interesting review of the aid literature, as well as the difficulties of measurement, see Qian (2014).

2 See for instance, Bayart (2000); Clapham (1996); Brown (2012); Whitfield (2009); Beswick and Hammerstad (2013); Chabal and Daloz (1999).

3 For instance, Lemarchand (2008).

4 The figures that are typically cited put the Tutsi at 14 per cent of the population, the Hutu at 85 per cent of the population, and the Twa at 1 per cent of the population in both countries. However, despite the widespread circulation of these figures, they are disputed and doubtful.

5 In French the CNDD-FDD is the Conseil National pour la Défense de la Démocratie- Forces pour la Défense de la Démocratie. 
ruling parties in both Rwanda and in Burundi were previously rebel movements engaged in wars against what they described as ethnically exclusive regimes.

Development assistance has been hugely significant in both countries across a wide range of sectors, both before the civil wars and afterwards. Rwanda has received higher levels of aid compared to Burundi, but both countries are highly aid dependent.

This paper makes three inter-related arguments. First, it shows that development assistance has been important in Rwanda and Burundi, but this assistance is not merely the result of independent decisions by donor countries and multilateral organizations, nor can it be explained by whether particular institutions and development 'conditions' were met by recipient countries. Rather, part of the aid story is about how ruling elites in recipient countries manage the aid relationship and its narrative. Second, despite destructive civil wars in Rwanda and Burundi and the emergence of new ruling parties and elites, both countries show a degree of resilience in terms of previous pre-conflict patterns of politics. The new ruling elites have used many similar governance strategies as their predecessors, with implications on donor relations. Third, while the RPF and the CNDD-FDD are, in part, the products of pre-conflict political structures, they have also been shaped by conflict and its aftermath. Military victory in Rwanda and protracted negotiated settlements in Burundi help explain the greater ability of the Rwandan government to manage and co-ordinate donors.

Taken together, these arguments show that aid is not an exogenous factor leading to particular development outcomes. Rather, aid is itself the product of particular histories, relations and interactions. Local elites in Burundi and Rwanda are not entirely 'free agents' as they are shaped and constrained by structures and histories, but they are not mere pawns of powerful international donors and their agendas. The contrast between Rwanda and Burundi is thus a contrast in how local agents negotiate the aid relationship.

The paper begins by briefly outlining key aid patterns in Rwanda and Burundi, and argues that it is important to understand the role of the ruling parties in influencing aid relationships. The paper then shows how the two rebel movements emerged from particular political, economic and social structures, and examines the impact of the civil wars and conflict endings. Finally, the paper shows how this affected the two ruling parties and their relations with donors.

\section{Development assistance in Rwanda and Burundi}

Rwanda and Burundi are both low-income countries. They are frequently compared since they are neighbouring states with historical, geographical, social and political commonalities. 6 As such, they constitute a 'most similar' type of comparison.

6 For instance, the following works use different comparative methodologies: Lemarchand (1970); Hintjens (2008); Bhavnani and Backer (2000); Turner (2013); Verwimp and D’Aoust (2013). 
Table 1: General indicators in Rwanda and Burundi

\begin{tabular}{lll}
\hline & Rwanda & Burundi \\
\hline Population (million), 2013 (UN estimates) & 11.78 & 10.16 \\
Size (sq km) (WB) & 26338 & 27834 \\
Population density (per sq km) & 447 & 365 \\
Human Development Index 2014 (rank out of 187 & 151 & 180 \\
countries) & 7.45 & 2.71 \\
GDP 2013 (WB) in US\$ billion & $8 \%$ & $4 \%$ \\
Growth 2012 (WB) & $(2013$ est. 5\%) & $(2013$ est. 4.5\%) \\
GNI per capita 2013 (WB) & US\$620 & US\$280 \\
\hline
\end{tabular}

Sources: Based on data from the World Bank and from the United Nations Development Programme.

Economic indicators are generally stronger in Rwanda than Burundi. Rwanda's GDP is higher and growth rates averaged more than 10 per cent per year between 1994-2004 and have been greater than 5 per cent a year since then, even after the global financial crisis IMF (2011). Rwanda is on target to achieve at least two of the Millennium Development Goals by 2015 in the fields of education and health care. Burundi has lower levels of private investment and is unlikely to meet any of the Millennium Development Goals. ${ }^{7}$ Agricultural productivity in Burundi is weak and among the lowest in Africa, particularly between 2000-05, though there was some improvement in 2008 (Nganou and Kebede 2012).

Rwanda has been called an 'aid darling', whereas Burundi has been called an 'aid orphan' (Marysse et al. 2007). As shown in Figure 1, Rwanda receives a greater volume of aid than Burundi, whereas the volume of aid in the two countries was more similar in the 1980s. A larger percentage of ODA in Burundi goes to humanitarian and emergency aid sectors, rather than in growth enhancing sectors of the economy. Both countries, however, remain highly dependent on foreign aid, and they both receive more aid today than they did before their civil wars. In Rwanda, net ODI/GNI was 18.5 per cent in 2010 and 20.1 per cent in 2011. In Burundi, net ODI/GNI was 31.3 per cent in 2010, 24.6 per cent in 2011 and 21.3 per cent in 2012.8 The relative dependence of the Rwandan government on aid has decreased from 85 per cent in 2000 to 45 per cent in 2010, but this is still a very high figure (Ansoms and Rostagno 2012). The identities of the largest donors to the two countries are roughly similar. The top four donors to Rwanda in 2011-12 were IDA (World Bank), the United States, the Global Fund to Fight AIDS, Tuberculosis and Malaria, and the United Kingdom. The top four donors to Burundi that same year were IDA (World Bank), EU institutions, Belgium, and the United States.?

\footnotetext{
7 House of Commons International Development Committee, The Closure of DFID's Bilateral Aid Programme in Burundi', Tenth Report of Session 2010-2012.

8 Figures from OECD-DAC, World Bank, www.oecd.org/dac/stats

9 OECD-DAC, World Bank, www.oecd.org/dac/stats
} 
Figure 1: ODA in Rwanda and Burundi (all sectors, all donors)

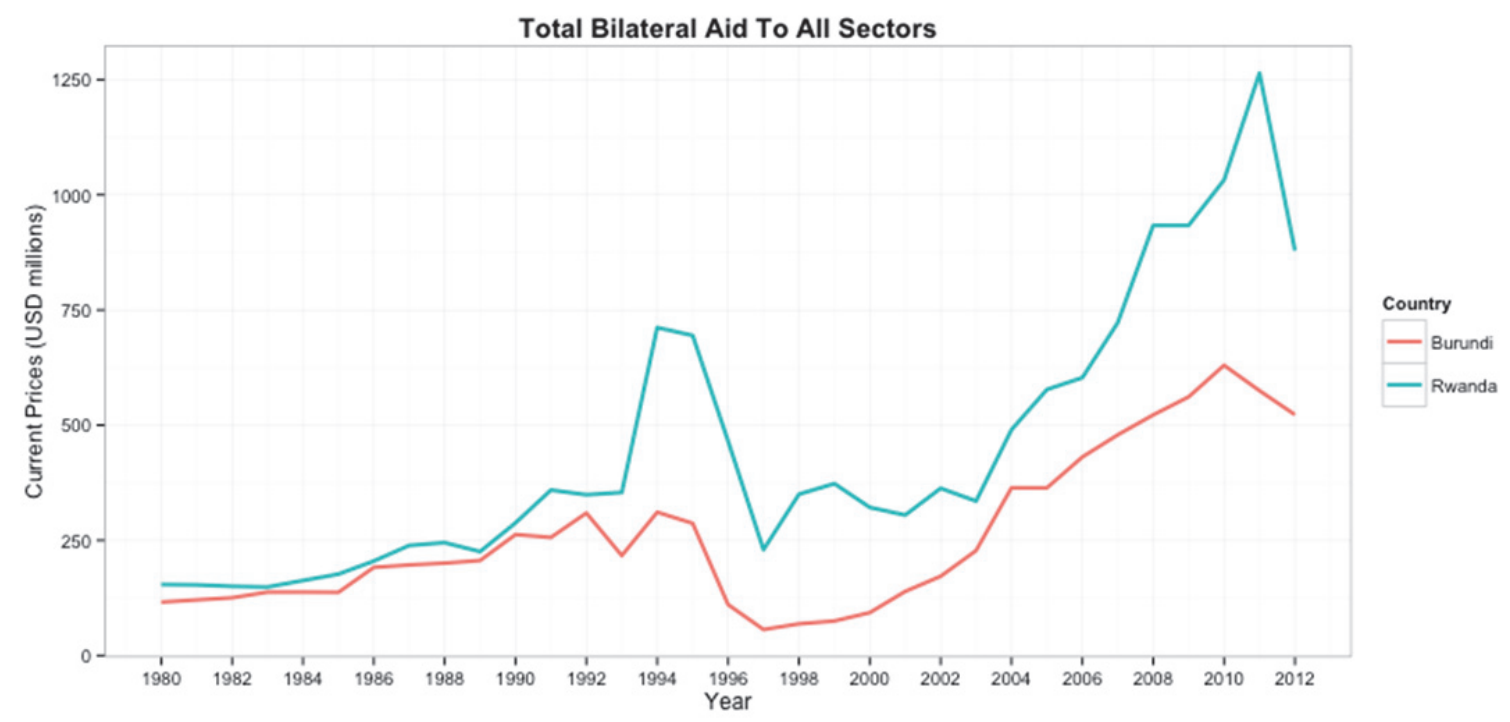

Source: Data from OECD-DAC (2013).

Thus, the two countries have had divergent post-war economic trajectories, even though they are both low-income countries heavily reliant on foreign assistance with similar histories and social structures. This has led some authors to conclude that aid has played a central role in the diverging post-war social development and economic performance of Rwanda and Burundi (Marysse et al. 2007: 433-58). Holmes et al. (2013) make a similar point about the advantages Rwanda has had due to its substantial budget support.

This paper does not engage with the debate about whether higher levels of aid caused better economic performance in Rwanda. Instead, it seeks to understand the nature of the aid relationship. Why does Rwanda receive higher levels of development assistance than Burundi? Some explanations emphasize the power of donor countries, their strategic interests, and their ability to use aid as a carrot and stick.10 In both Rwanda and Burundi, levels of aid have fluctuated over time, which appears to support views that emphasize donor agency and changing donor priorities. As seen in Figure 1, aid levels to Rwanda rose sharply in 1993 with the signing of a peace agreement and the deployment of a UN peacekeeping mission. Aid dropped dramatically in the aftermath of the 1994 genocide, rising steadily again from 1997. In 1998, Rwanda re-established relations with the IMF through its Enhanced Structural Adjustment Facility Programme. There was a drop in development assistance from 2012, in response to concerns over the Rwandan government's activities in the Democratic Republic of the Congo (DRC) and its treatment of the political opposition.

In Burundi, ODA decreased during the war and especially in 1996 due to sanctions that were placed on the country following a military coup. The Arusha Peace Agreement was signed in 2000 and a transitional government was instigated in 2001. Burundi re-established relations with the IMF in 2001 and ODA steadily increased, especially after the 2005 elections. In 2006 Burundi was one of the first countries on the new United Nations Peacebuilding Commission. From 2007 onwards, Burundi therefore received funds from the Peacebuilding Fund, which was set up to help fund quick impact projects in the aftermath of conflict. Aid dropped in 2010 due to donor concerns over financial scandals and governance after the elections that year.

10 See for instance, Schraeder et al. (1998). 
These trends may give the appearance that donors set the aid agenda and that local agency is limited. However, donor decisions about their aid commitments and disbursements are not separate from the politics of recipient countries. To understand the aid relationship it is necessary to unpack the Rwandan and Burundian sides of the relationship.

According to some authors, higher levels of development assistance are given to Rwanda because the country has shown that it can use the funds effectively. Marysse et al. (2007) say that when making decisions about aid allocation, donors look at the technocratic elements of governance such as government effectiveness, the regulatory burden, corruption, and rule of law, instead of political sensitivities, meaning that Rwanda is an attractive recipient. In 2010, Rwanda was ranked 67th out of 143 countries in the Doing Business Report, and was called the world's top reformer (World Bank 2010). Likewise, Rwanda scores well on UNDP's Gender Inequality Index. It has the highest percentage of women in the national parliament, and a high percentage of women participating in the labour force (UNDP 2011). Thus, Rwanda appears to fulfil many internal requirements for increased donor funds.

Institutions in Burundi tend to be weaker than Rwandan ones. Transparency International ranked Burundi 172 out of 182 countries, claiming it to be one of the most corrupt countries in the world. Burundi has a limited capacity to mobilize revenues, so aid finances the state (ADB 2010). It lacks aid absorption capacity, and many donors have not used national systems. Weak capacity has also affected monitoring capacity, which further affects accountability (Desrosiers and Muringa 2012). The financial sector in Burundi is used as a source of rents rather than development finance, and thus has not had a significant effect on economic development (Nkurunziza 2010; Nkurunziza et al. 2012). In 2011 in Burundi, a Vision 2025 document was released by the government, which articulated a vision of goals for the country for 2025, including an annual GDP growth of 10 per cent and the reduction of the poverty rate. 11 It is unclear, however, that these goals will be met.

The presence or absence of effective institutions and policies in recipient countries may help us understand the impact of aid, but it does not explain how and why such institutions and policies came about, and how they are presented and interpreted by donors. To understand differences in Rwandan and Burundian post-war donor relationships, it is helpful to consider how the two ruling parties manage and influence donors. The Burundian CNDD-FDD is a weaker party than the RPF in Rwanda, and has less leverage vis-à-vis donors, despite the CNDD-FDD's greater domestic democratic legitimacy. The RPF is better able to co-ordinate and manage donors compared with its Burundian counterpart, and to channel assistance into priority areas. These differences can in part be explained by how the two movements were created and how they evolved.

The emergence of the RPF and the CNDD-FDD

While the CNDD-FDD and the RPF are both former rebel movements, they emerged from different systems with different constraints. Jeremy Weinstein's research shows that the strategies used by rebel groups during civil wars, including how they treat civilian populations, depend on the environments in which the group originated and the types of resources that they are able to mobilize (Weinstein 2007). Others have argued that the organizational structures and context of

11 Ministry of Planning and Communal Development, Complete Vision 2025, June 2011, accessed at: http://www.bi.undp.org/content/dam/burundi/docs/publications/UNDP-bi-vision-burundi2025_complete_EN.pdf 
a rebel movement continue to influence its transition to a political party, and several case studies show that there are important elements of continuity linking political parties to their prior structures as rebel organizations. 12 As Sara Dorman explains, rebellions that aim to 'liberate' populations from oppressive rule often have a well-articulated ideology to attract recruits and civilian supporters and to present to the media, academics and donors. Dorman argues that relationships that were established as a guerrilla movement affect the party's mode of governance later. In other words, the legacies and institutional practices of the rebel movements tend to play themselves out in post-liberation years (Dorman 2006).

The RPF and the CNDD-FDD emerged in different political circumstances, but there were important parallels in the histories of the two countries that influenced later governance. First, neither Rwanda nor Burundi is an artificial creation of colonial rule, unlike many other African states. They had pre-colonial centralized state structures and the kingship was the focus of popular loyalties and factional struggles in the two countries. So, both states are strongly socially anchored, with current boundaries that closely mirror pre-colonial political boundaries. Compared to Rwanda, however, the Burundian Kingdom was less centralized, and the Mwami (King) was more dependent on popular support (Lemarchand 1970).

Second, following Independence on 1 July 1962, both states were strongly authoritarian. After a coup in 1973, when President Habyarimana took power in Rwanda, the MRND (National Revolutionary Party for Development) became the only party. Life was very tightly controlled and Rwandans could not move from one prefecture to another without permission. The state was centralized and hierarchical, with five levels of administration. Thus, the state had an extensive presence at the local level, and controlled many aspects of Rwandan social life (Newbury 1992). 13

Similarly, before the 1990s there was one party in Burundi, UPRONA (the Union for National Progress), and social mobility depended upon participation in the party. The party was linked to the country's only women's movement, youth organization, the one radio station, and the only newspaper (Lemarchand 1994). The state was characterized by centralization and penetration, meaning that control stretched down to the lowest strata of social structures (Ndikumana 2005). The economies of both countries were organized through generalized patrimonial rent-seeking. Small business entrepreneurs in both Rwanda and Burundi depended upon having patrons within the administration or the military.

A third feature in both countries is that power structures were ethnically exclusive and regionally divided. Whether the Hutu/Tutsi distinction was historically a racial or a social class difference is contested, but ethnic categories became more rigid under Belgian rule (Mamdani 2002; Lemarchand 1994). While the ethnic composition of the two countries was similar, the basis for post-Independence exclusion was different. In Rwanda, following the 1959 Revolution and the overthrow of the Tutsi monarchy, many Tutsi fled to refugee camps in neighbouring Uganda,

12 Bøås and Dunn (2007); Reno (2011); Manning (2004: 54-77). Also, Clapham (1998) has developed a typology of rebel movements with rich case analyses.

13 In the post-genocide period, RPF initiatives such as community justice and decentralization were justified on grounds of 'tradition' or of 'efficiency', but they led to an extension of state power, which resonates with the past. Bert Ingelaere, drawing on Alison Des Forges' work, shows how peasants in contemporary Rwanda explain the post-genocide present in terms of the pre-colonial past (Ingelaere 2011: 67-78). 
and the majority Hutu dominated post-Independence governments. ${ }^{14}$ In Burundi, it was the minority Tutsi that dominated post-Independence political, military, and economic structures. 15

Fourth, development assistance played an important role in both countries before their civil wars. As Peter Uvin has noted, Rwanda was seen as a 'model of development in Africa' before the genocide, with strong development indicators such as high GNP growth and growing industrial production. It also had strong human development indicators such as high vaccination rates and a vibrant civil society (Uvin 1998). 16 In Burundi, the Tutsi ruling class used the language of national unity and development in order to garner legitimacy, particularly under the Presidency of Bagaza from 1976. Unifying symbols such as the independence hero Prince Louis Rwagasore were propagated, and there was a denial of ethnicity (Lemarchand 1994; Vandeginste 2014). There was a policy of villagization to increase agricultural yields and to promote 'modernization'. At times there were tensions with donors, but Bagaza was successful in attracting development assistance (Scherrer 2002).

Thus, the RPF and the CNDD-FDD emerged in two countries with a history and tradition of strong statehood. Ethnically exclusive post-Independence governments had high levels of authoritarianism and social control, and also high levels of development assistance.

Significantly however, the RPF has its origins outside Rwanda, whereas the CNDD-FDD was a breakaway group from a political party within Burundi. The RPF can be traced to Tutsi refugees that fled to Uganda following the Rwandan revolution of 1959. The Tutsi refugee community formed the Rwanda Refugees Welfare Association, which was later renamed the Rwandan Alliance for National Unity (RANU) in 1979. Persecutions against the refugees grew increasingly severe after the fall of Idi Amin in 1979, and many young Rwandan Tutsi men joined Yoweri Museveni's National Resistance Army (NRA) guerilla movement. In January 1986 when Museveni and the NRA captured Kampala, his force included an estimated 3000-4000 Tutsi Rwandan fighters. In December 1987, RANU changed its name to the more militant Rwandan Patriotic Front (RPF). In October 1990, the RPF invaded Rwanda, saying that they wanted to return to their homeland (Otunnu 1999). This invasion occurred at the same time as the Rwandan regime faced economic vulnerabilities due to a drop in food production and a drop in coffee prices, 17 as well as political vulnerabilities due to pressures from donors to open political space in the context of the post-cold war enthusiasm for democracy.

Initially, therefore, RPF members were recruited from the armed forces of a foreign power. The RPF was highly influenced by the ideas and structures of the Ugandan NRM/NRA, as well as other revolutionary movements such as Mozambique's FRELIMO party. The RPF fighters were well-trained and highly disciplined. The first two leaders of the RPF, Fred Rwigyema (killed in battle in 1990) and Paul Kagame (the current President of Rwanda) were senior figures in the NRA.18 The RPF claimed to be liberating Rwanda, yet in the early stages of war even Rwandan

14 The first post-Independence President, Gregoire Kayibanda (1962-1973), drew his support mainly from the south, whereas the next President, Juvenal Habyarimana (1973-1994) was supported mainly by northern Hutu.

15 Post-Independence Presidents Micombero (1966-1976), Bagaza (1976-1987) and Buyoya (1987-1993, 1996-2003) were all Tutsi from the same clan and commune in Bururi province.

16 Uvin (1998) argues that the development aid system in Rwanda interacted with political and social processes that made genocide possible, such as the processes of social exclusion. See also Andersen (2000: 441-56).

17 The government increased borrowing to keep up its expenditures, so foreign debt began to rise. In 1991, Rwanda signed a US\$90 million structural adjustment programme with the World Bank (Storey 2001).

18 Rwigyema had been Deputy Commander of the NRA and Major Paul Kagame had been Head of Intelligence and Counter-Intelligence. 
Tutsi ran away from the RPF (Prunier 1998). The RPF could not recruit young men from the local population in classic guerilla fashion, since the RPF did not have the support of the Rwandan population in whose name they were fighting. Instead, young Tutsi exiles from all over the Rwandan diaspora but especially from Uganda joined to fight in a country that they did not know. This began to change in late 1992, when the RPF started recruiting from the Tutsi population within Rwanda as the Rwandan government's anti-Tutsi rhetoric increased.

Unlike the RPF and its foreign origins, the Burundian CNDD-FDD has its origins as a breakaway faction of the FRODEBU political party that had won the 1993 elections. These elections, which had been heavily promoted by international actors, led to a veritable reversal of power, with a mostly Hutu party FRODEBU winning over the incumbent mostly Tutsi party UPRONA that had dominated since Independence. The new FRODEBU President Melchior Ndadaye was assassinated by members of the Tutsi-dominated army three months after taking office, leading to widespread massacres across the country. Unable to control the country, FRODEBU members were divided over whether or not to share power with the former ruling party UPRONA. FRODEBU reluctantly agreed to share power, but some members refused, led by Leonard Nyangoma. Nyangoma and his associates created a military wing called the CNDD, which aimed to re-capture political power by force and to instigate army reform. ${ }^{19}$

The CNDD thus emerged as a more radical wing of an established political party in Burundi, even though at various times during the subsequent civil war the CNDD had rear bases in Tanzania and in the Democratic Republic of the Congo.20 Many of the CNDD leaders were former heads or deputies in FRODEBU, though by 1996, the executive committee of the CNDD became independent from FRODEBU (Nindorera 2012).

Due to shifting alliances, regional dynamics and financial considerations, the CNDD split several times. There were frequent clashes with the other Hutu armed movement, the Palipehutu-FNL, and tensions within the CNDD between members from different regions and religions (Nindorera 2012). In 1998, Nyangoma was ousted by Jean-Bosco Ndayikengurukiye and the movement was renamed the CNDD-FDD. 21 It split again in 2001, and Pierre Nkurunziza, the current President of Burundi, became the leader. Nkurunziza and his faction of the CNDDFDD stayed out of the regionally sponsored Arusha peace negotiations to end the Burundian civil war. Even once the Arusha peace agreement was signed and the Burundian transitional institutions were established, the CNDD-FDD continued to wage war.

Therefore, the CNDD-FDD and the RPF were both rebel movements seeking to influence and capture state power, but they were very different kinds of organizations. The RPF was highly trained and disciplined, with a strong focus on political education. The movement was divided into different zones and sectors, and was very well organized and coherent. In contrast, the CNDD-FDD was constantly affected by desertions and realignments, depending on alternative opportunities for leaders and fighters. The CNDD-FDD leadership had profound disagreements over whether and when to join peace negotiations, whether to share power, and how to engage with international and regional mediators. Furthermore, the CNDD-FDD was competing with other Hutu rebel movements in Burundi, particularly the Palipehutu-FNL.

19 Another Hutu rebel movement called the Palipehutu had formed earlier in the Tanzanian refugee camps in 1980. Many Palipehutu members were refugees who had fled Burundi during the 1972 genocide. See Malkki (1996).

20 For an excellent discussion of the origins and evolution of the CNDD-FDD, see Burihabwa (2015).

21 Nyangoma retained control of the CNDD, which became a political party with little popular support. 
Thus, while the RPF had little in the way of links to the Rwandan population inside the country, they were a coherent, disciplined, well-structured organization. The CNDD-FDD had more domestic popular support, but was a more internally fragmented organization.

\section{$4 \quad$ Military victory and negotiated settlement}

The Rwandan conflict ended with the military victory of the RPF in July 1994, whereas the Burundian conflict ended through protracted negotiated settlements, leading to democratic elections won by the CNDD-FDD in 2005. These different conflict endings have important ramifications both in terms of governance and institutions, as well as subsequent relations with donors.

When the RPF took over as ruling party in Rwanda, many members of the former regime were in refugee camps in Zaire, in other neighbouring countries, or overseas. The RPF reaffirmed its commitment to the terms and the spirit of the internationally-sponsored 1993 Arusha Accord and to the logic of power-sharing. The former single-party, the MRND, and the extremist Hutu party CDR were banned, but other political parties took up their seats in a National Unity government and parliament as set out by the Arusha Accord. Nonetheless, the decisive military victory meant that the RPF had tight military control over the country, and this enabled the RPF to re-establish social and political control relatively quickly.

Relations between the RPF and some donors became close in a reasonably short space of time. Aside from France, which had provided extensive support to the previous Rwanda regime (Wallis 2006), most western donors and diplomats were reluctant to question the good faith of the new RPF rulers, even as a number of human rights organizations began to outline some of the questionable practices of the new regime.22 The USA, UK and the Netherlands were particularly important donors. These countries were relative newcomers to Rwanda and saw the country's politics in terms of good guys versus bad guys, with the RPF as the good guys. For instance, the UK Department for International Development (DFID) viewed Rwanda as a 'special case' that needed to be supported (Marriage 2006). Western governments had been criticised for their inaction during the genocide, but they were now committed to assisting reconstruction through development (Hayman 2010).

Thus, the way in which conflict ended in Rwanda led to increased centralized control by the $\mathrm{RPF}$, and the 'guilt' over the lack of international response to genocide gave the RPF greater legitimacy and policy independence vis-à-vis donors. Donors, especially those with little previous experience in Rwanda, were eager to contribute to reconstruction efforts and were receptive to the narratives being articulated by the RPF (Hayman 2009).

In Burundi, the negotiated settlement to civil war brought about a very different dynamic. The war in Burundi and the protracted peace negotiations contributed to the fragmentation of the state (Uvin and Bayer 2013). The Arusha Agreement was signed by 19 parties in 2000 but the CNDD-FDD was not a signatory, as it had stayed out of the internationally and regionallybrokered negotiations. Burundian transitional institutions were set up from 2001, but the CNDD-FDD continued to fight, claiming that the peace process was not legitimate. The Burundian transitional leadership, regional mediators and international diplomats tried to entice the CNDD-FDD leadership into the peace process and transitional institutions through a mixture of carrots and sticks. In late 2003, a ceasefire agreement was reached which gave key

22 See, for instance, Amnesty International (1994) and Human Rights Watch (1994). 
CNDD-FDD leaders important cabinet portfolios in the transitional government, and also guaranteed that CNDD-FDD commanders would be given positions within the army and police. 23

During the transitional phase, donors in Burundi were relatively well co-ordinated. The UN coordinated multiple diplomatic initiatives. Although there were some important differences among donors, there was a common sense of what needed to be achieved, namely a comprehensive cease-fire, army reform and democratic elections (Uvin 2010).

In 2005, the CNDD-FDD won multi-party democratic elections by a significant margin and former rebel leader, Pierre Nkurunziza, became President. One of the reasons for the CNDDFDD's popularity was that it was not associated with the extended Arusha peace process, which many Burundians viewed as an elite-driven exercise that had enriched politicians in the capital Bujumbura. Furthermore, many Burundians across the country believed that the CNDD-FDD was the party that could bring security to a war weary population. Nonetheless, Burundi remained highly divided, with elites scrambling to strategically re-position themselves to take advantage of the new political landscape and the power-sharing requirements in the new Constitution (Curtis 2013).

The extensive and prolonged negotiations to end the Burundian conflict therefore contributed to the further factionalization of Burundian political space but also had important consequences on CNDD-FDD relations with the donor community. International and regional facilitators were much more accustomed to working with other Burundian parties, particularly UPRONA and FRODEBU, since the CNDD-FDD had stayed out of the peace process for such a long time. There were thus strong personal and professional connections between UPRONA and FRODEBU and international donors and diplomats, whereas the CNDD-FDD representatives were relatively unknown (Jackson 2006).

In contrast to the RPF then, the CNDD-FDD gained domestic legitimacy through popular support expressed in what was largely regarded as a fair democratic contest. Yet the very nature of negotiated settlements, particularly the carefully balanced Burundian power-sharing settlement, meant that politics and power in Burundi were much more fractured and diffuse than in Rwanda. In Rwanda, military victory, a receptive international audience due to guilt over the genocide, and the RPF's tight internal hierarchical structure meant that it was easier for the party to exert effective social and political control and to articulate a consistent narrative vis-à-vis donors.

\section{$5 \quad$ Local agency and donor relations}

The nature of the two ruling parties and the way in which they came to power thus have important implications in terms of donor relations. In Rwanda, the post-genocide political record of the RPF is a matter of enormous disagreement. Critics focus on human rights abuses committed by the RPF against political opposition figures, as well as in the DRC. It is difficult to openly express one's views in Rwanda, including the expression of political identities that fall outside of officially circumscribed spaces and categories (Reyntjens 2011). ${ }^{24}$ Critics also say that Rwanda's high growth rates hide large and growing vertical and horizontal inequalities in the

23 For details of the various agreements Curtis (2013); Vandeginste (2011).

24 Due to this repression, challenges to RPF authority and hegemony are largely expressed outside of Rwanda by the Rwandan diaspora, particularly in the DRC, South Africa and Europe. 
country (UNDP 2007). Government policy is to concentrate land-holdings and modernize agriculture through intensification, leading to large gaps between the urban elites in Kigali and small-scale farmers (Ansoms 2009). There are ambitious, top-down rural development schemes designed to encourage villagization, commercialize production, and promote regional crop specialization, with harsh penalties for non-compliance (Newbury 2011). Supporters of the regime, on the other hand, point to economic success and notable progress on a range of social and economic indicators, despite a very difficult history. 25 They praise the RPF for being able to build a strong, relatively legitimate state (McDonough 2008).

Both critics and supporters, however, point to the ability of the RPF to exert considerable agency in the donor relationship. Despite its heavy reliance on donors, the RPF has achieved a high level of political autonomy (Hayman 2009). The Rwandan government implemented a 'traffic light system' that scores donors on the degree to which they provide budget support and use the government's own financial systems (Ansoms and Rostagno 2012).

There are several dimensions of the RPF narratives and policies, which have increased its ability to direct and effectively manage donor relations. 26 First, military victory by the RPF helped it gain a near monopoly over information and the production of knowledge about the history of the genocide. Aid workers, international (mainly anglophone) journalists, scholars and donors who arrived in Rwanda in the immediate aftermath of genocide often knew very little about the country and were willing to accept the new government's version of the truth (Pottier 2002). Furthermore, the RPF actively cultivated close diplomatic, aid and intelligence relations with the USA and the UK (Hintjens 2008; Beswick 2010). Due to its origins in Uganda, many RPF officials speak English very well and have emphasized donor favourites such as gender equality and effective governance, while simultaneously pursuing its own political agenda (Reyntjens 2011).

Second, the RPF claims to be the bearer and symbol of a new unified Rwanda, and these unity and reconstruction narratives resonated with donors. According to the RPF, it is a country that has successfully transformed, with the RPF as the central actor in leading the country towards recovery and reconciliation. 27 In the absence of popular support within Rwanda, the RPF uses memory and memorialization of the genocide as a means to justify its power. 28 The RPF thus portrays itself as the symbol of a new unified Rwanda where ethnic identities no longer matter. It is no longer acceptable to refer to Rwandans according to the ethnic categories of Hutu or Tutsi or Twa, which the RPF claims can be directly traced to European colonial racial ideologies, incompatible with modernity. 29 Instead, the categories in Rwandan legal and administrative documents are derived from the official RPF reading of the genocide: survivor, old caseload returnee, new caseload returnee, suspected genocidaire (Hintjens 2008). Furthermore, the RPF presents itself as an essential bulwark against the risk of future genocide, and has used this justification to pass legislation, such as the genocide ideology law of 2008, which remove voices of dissent or opposition (Waldorf 2009).

25 For a clear articulation of the RPF view of history and of the problems of the present, see Murigande (2008). Murigande was the Rwandan Foreign Affairs Minister when he wrote this piece.

26 Jonathan Fisher calls this the ability of the RPF to provide a 'donor support rationale'. Fisher (2013).

27 Rwandan peasants' 'hidden' resistance to this narrative is outlined in Thomson (2011).

28 There has been extensive international support for the Rwandan government's project of memorialization (Ibreck 2013).

29 The reconstruction of ethnic and political identities has been carried out by a number of institutions, including a fund for survivors, a National Unity and Reconciliation Commission, and a National Human Rights Commission. Solidarity camps were set up to re-educate Rwandans about their past. See Straus and Waldorf (2011). 
Third, the RPF has redefined itself as a liberation movement offering modernity, development and progress. While the RPF cannot draw upon democratic legitimacy, it derives its legitimacy from its economic progress, or what is sometimes called 'performance legitimation'. Interestingly, this is reminiscent of earlier government strategies. In the 1970s, despite exclusionary and authoritarian governance, the Rwandan government garnered legitimacy through the discourse of successful 'development'. In 1974, the Rwandan parliament was renamed the National Development Council and the President announced that Rwanda's 143 communes would be the 'motors of development' (Uvin 1998). Today, some authors say that Rwanda should be characterized as a developmental patrimonial state, albeit with some qualifications (Booth and Golooba-Mutebi 2012).30 The RPF wholly owns the private sector holding company Tri-Star Investments/Crystal Ventures Ltd (CVL) and has majority stakes in many other leading Rwandan companies. 31 Profits from the operation of subsidiaries are taxed and either reinvested or returned as dividends to the RPF (Booth and Golooba-Mutebi 2012). This has led to centralized rent management, which explains why Rwanda is sometimes called the 'Singapore of Africa'.

Fourth, the RPF has positioned itself as being central to efforts to bring security to unstable parts of Africa (Beswick 2014). It has a highly trained military, and is currently the sixth largest troop and police contributor to the UN. 32 Rwanda deployed its first peacekeepers to the African Union Mission in Sudan in 2004. Since then, it has contributed, among others, to the AU-UN Hybrid Operation in Darfur (UNAMID), the UN Mission in South Sudan (UNMISS), the UN Stabilization Mission in Haiti (MINUSTAH), the UN Mission in Liberia (UNMIL), the UN Interim Security Force in Abyei (UNISFA), the Operation in Côte d'Ivoire (UNOCI), the UN Peacebuilding Office in Guinea-Bissau (UNIOGBIS), and to the African-led International Support Mission in the Central African Republic (MISCA). 33 These contributions should not be underestimated. When Rwanda was criticised in the 2010 draft report of the UN Panel of Experts, the Rwandan government warned that it could withdraw its peacekeepers from Darfur (Gettleman and Kron 2010).

Fifth, RPF rhetoric mirrors the language of local ownership and African solutions. For instance, RPF officials often use the language of the 2005 Paris Principles on Aid Effectiveness (Zorbas 2011). The Rwandan government developed its 'Vision 2020' policy guidelines, outlining targets and goals to transform Rwanda into a middle-income country by 2020 (Government of Rwanda 2000). Given the RPF's skill at using ownership language that appeal to its most important donors, the international donor community has been inclined to follow the priorities and plans set by the government.

Thus, the RPF has been successful in managing donors and controlling the narrative about its post-conflict trajectory. Nevertheless since 2010, criticism of Rwanda among many donors has increased. In 2012, key donors including the USA, UK, Germany and the Netherlands delayed disbursement or withdrew part of their aid due to renewed allegations by the UN that Rwanda

\footnotetext{
30 Booth and Golooba-Mutebi (2012) make a distinction between patterns of rent-seeking in pre-1994 Rwanda and rent seeking under the RPF.

31 Tri-Star emerged from the RPF's war-time 'Production Unit', which generated funds for the RPF as a rebel movement, and helped fund the government in the immediate aftermath of the genocide.

32 From http://www.un.org/en/peacekeeping/resources/statistics/contributors.shtml

33 From http://www.gov.rw/Rwanda-deploys-peacekeeping-troops-to-help-stabilise-the-Central-African-Republic
} 
was supporting M23 rebel activity in the DRC.34 It is too early to say if this marks a fundamental shift in donor relations, or a temporary recalibration.

Burundi, on the other hand, has been consistently unable to exert the same kind of leverage over international donors. The negotiated settlement to conflict in Burundi, the politics of accommodation, and the divided power-sharing political landscape have led to competing poles of power within Burundi. The RPF has maintained tight discipline within the party, with detractors forced to go into exile. In Burundi, constitutional provisions for power-sharing has meant that the CNDD-FDD is required to include dissenting voices within the party, and it has recruited many prominent Tutsi within its ranks. As described above, the CNDD-FDD never had the same level of discipline as the RPF, due to the different conditions it faced in its armed struggle. Indeed, Nindorera (2012) points out that the same neo-patrimonial but factionalized practices that currently characterize the Burundian government, also characterized the earlier CNDD.

One might have expected that a Burundian emphasis on democracy, inclusivity, and shared power would appeal to donors, especially since international and regional actors were instrumental in the establishment of the Burundian power-sharing system. Yet the CNDD-FDD has been unable to articulate a narrative that resonates with donors. At the time of its creation, throughout its armed struggle, as well as during the post-conflict period, the CNDD-FDD has been a fractured organization with competing voices that have hindered the emergence of such a narrative. Even though the Burundian political environment stands in marked contrast to the Rwandan one, with its multi-party elections and more inclusive political space, it has not been possible for the CNDD-FDD to put forward a compelling narrative based on democracy, rights and inclusivity. In part this is because the CNDD-FDD has increasingly turned to more authoritarian tactics and governance strategies, particularly since its electoral victories in 2005 and 2010. The CNDD-FDD has tried to tighten its control of state companies, provincial governorships and the court system. It is seeking to assert itself as only legitimate decision-maker that can distribute the spoils of office in return for loyalty. Thus, a narrative of democracy is not fully credible.

The CNDD-FDD is also unable to put forward a narrative based on economic performance and management. In general, the aid system in Burundi has supported and even strengthened the neo-patrimonial system that benefits the ruling elite (Uvin and Bayer 2013). Economic relations are largely neo-patrimonial, as in Rwanda, but since structures are more fractured in Burundi, patrimonialism is less likely to be developmental. In other words, the CNDD-FDD is not able to be directive in the same way as the RPF. Decentralization in Burundi was reintroduced in 2005, but this reinforced non-developmental neo-patrimonial political structures (Gaynor 2014).

Furthermore, as outlined above, when the CNDD-FDD won the 2005 elections, relations with the UN mission in Burundi were strained, in part because the international donor community was accustomed to dealing with the two other main political parties (Jackson 2006). CNDDFDD officials perceived the UN and other international actors to be biased, and felt that since their party had won the elections, the UN mission should leave governance tasks to the new democratically-elected government. As relations grew worse, international donors described the CNDD-FDD as inexperienced, intransigent, authoritarian and in need of 'training'. 35 CNDD-

34 The UK decided not to release $f_{2} 21$ million in support to Rwanda due to the Rwandan government's support of the M23 rebel movement in eastern DRC. In March 2013, f16 million of this aid was reprogrammed, channelled through projects rather than as direct budget support. See DFID Ministerial Statements, 30 November 2012, and 1 March 2013.

35 See for instance, International Crisis Group (2006). 
FDD officials used the language of sovereignty, legitimacy and autonomy, in an attempt to loosen donor influence and to exert their control and agency. Several of the most senior UN officials in the country, including successive United Nations Special Representatives of the Secretary-General, Carolyn McAskie and Nureldin Satti, as well as Executive Representative of the Secretary-General and Head of the UN Integrated Peacebuilding Office in Burundi, Youssef Mahmoud, were asked to leave the country by the government.

Despite these attempts to assert its autonomy, the CNDD-FDD has not been able to coordinate or direct donors in the same way as the RPF. A number of institutions have been set up to manage relations, such as the National Committee for the Co-ordination of Aid, established in 2005. A permanent secretariat for this National Committee was established to monitor aid flows and increase coherence and co-ordination, to support the government's implementation of the Paris Principles, and to serve as the secretariat for the Partners Co-ordination Group (Desrosiers and Muringa 2012). However, in practice, while the government has embraced the aid effectiveness agenda, it has not been able to implement many of the principles (Desrosiers and Muringa 2012). Since donors largely mistrust Burundian institutions, they often work outside these national structures. This leads to a very different dynamic compared to Rwanda.

Lastly, the CNDD-FDD has tried to exert agency through security narratives. Like Rwanda, Burundi has contributed a significant number of troops to African Union peacekeeping missions, most notably to the African Union Mission to Somalia (AMISOM) as well as to MISCA. The CNDD-FDD has tried to justify its harsh and unlawful treatment of opposition members with language echoing the Rwandan security discourse. While this security language has perhaps mitigated donor criticism to a small extent, the Burundian government has been unable to exert the same level of autonomy as its Rwandan neighbour.

\section{6}

\section{Conclusions}

In a continent where international policymakers and donors continually bemoan the weakness of the state, Rwanda and Burundi stand out as exceptions. The RPF, in particular, operates within a strong state but relies upon exclusivist modes of authoritarian rule couched in the language of recovery and modernization. Political authority in Burundi is more fractured, and patrimonial networks in Burundi have not succeeded in bringing about the same levels of development as in Rwanda.

Despite its past and present human rights violations, the RPF maintained its image as an effective modernizer in the eyes of many international donors, which has only started to be seriously challenged by donors in the past three years. The RPF has consistently emphasized the country's economic accomplishments as an alternative (African) source of internal legitimacy. Paradoxically, while the CNDD-FDD has not been as successful as the RPF in directing donor funds and managing aid relationships, the Burundian state may end up being more robust due to its more inclusive institutions, although the worsening security environment and increasing authoritarianism in Burundi mean that the trajectories of both countries remain uncertain.

It is tempting to attribute Rwanda's relative success to the role of donors and foreign aid. This, however, would be insufficient. Instead, this paper has shown that international donor involvement itself is, in part, a product of very different war-time trajectories. Aid is a consequence of particular relationships, not only a cause, and ruling elites in recipient countries play a critical role in constructing that relationship. Part of the difference between Rwandan and Burundian aid relationships can be explained by the different political contexts leading to the emergence of the RPF and CNDD-FDD, their different internal structures, and the different 
ways that their civil wars ended. The RPF is a stronger party. This does not necessarily lead to 'better governance', but it has led to more policy autonomy and different patterns of engagement with international donors.

\section{References}

African Development Bank (ADB) (2010). 'Domestic Resource Mobilization for Poverty Reduction in East Africa: Burundi Case Study'. African Development Bank.

Amnesty International (1994). Reports of Killings and Abductions by the Rwandese Patriotic Army, April-August 1994. London: Amnesty International.

Andersen, R. (2000). 'How Multilateral Development Assistance Triggered the Conflict in Rwanda'. Third World Quarterly, 21(3): 441-56.

Ansoms, A. (2009). 'Re-Engineering Rural Society: The Visions and Ambitions of the Rwandan Elite'. African Affairs, 108(431): 289-309.

Ansoms, A., and D. Rostagno (2012). 'Action Aid, 'Real Aid: Ending Aid Dependency'. Cited in 'Rwanda's Vision 2020 Halfway Through: What the Eye does Not See'. Review of African Political Economy, 39(133): 429.

Bayart, J.F. (2000). 'Africa in the World: A History of Extraversion'. African Affairs, 99: 217-267.

Beswick, D. (2010). 'Managing Dissent in a Post-Genocide Environment: The Challenge of Political Space in Rwanda'. Development and Change, 41(2): 225-51.

Beswick, D. (2014). 'The Risks of African Military Capacity Building: Lessons from Rwanda'. African Affairs, 113(451): 212-31.

Beswick, D., and A. Hammerstad (2013). 'African Agency in a Changing Environment: Sources, Opportunities and Challenges'. Conflict Security and Development, 13(5): 471-86.

Bhavnani, R., and D. Backer (2000). 'Localized Ethnic Conflict and Genocide: Accounting for Differences in Rwanda and Burundi'. Journal of Conflict Resolution, 44(3): 283-306.

Bøås, M., and K.C. Dunn (eds) (2007). African Guerrillas: Raging Against the Machine. Boulder CO: Lynne Rienner.

Booth, D., and F. Golooba-Mutebi (2012). 'Developmental Patrimonialism? The Case of Rwanda'. African Affairs, 111(444): 379-403.

Brown, W. (2012). 'A Question of Agency: Africa in International Politics'. Third World Quarterly, 33(10): 1889-1908.

Burihabwa, N. (2015). Unpublished PhD dissertation (forthcoming).

Chabal, P., and J.P. Daloz (1999). Africa Works: Disorder as Political Instrument. London: James Currey.

Clapham, C. (1996). Africa and the International System: The Politics of State Survival. Cambridge: Cambridge University Press.

Clapham, C. (ed.) (1998). African Guerrillas. Bloomington: Indiana University Press.

Curtis, D. (2013). 'The International Peacebuilding Paradox: Power Sharing and Post-Conflict Governance in Burundi'. African Affairs, 112(446): 72-91.

Desrosiers, M.E., and G. Muringa (2012). 'Effectiveness under Fragile Conditions?: Sociopolitical Challenges to Aid and Development Cooperation in Burundi'. Conflict, Security and Development, 12(5): 501-36. 
Dorman, S. (2006). 'Post-liberation Politics in Africa: Examining the Political Legacy of Struggle'. Third World Quarterly, 27(6): 1085-1101.

Fisher, J. (2013). 'Structure, Agency and Africa in the International System: Donor Diplomacy and Regional Security Policy in East Africa since the 1990s'. Conflict, Security and Development, 13(5): 537-67.

Gaynor, N. (2014). 'Bringing the Citizen Back In: Supporting Decentralisation in Fragile States A View from Burundi'. Development Policy Review, 32(2): 203-18.

Gettleman, J., and J. Kron (2010). 'Rwanda Threatens to Pull Peacekeepers from Darfur'. In New York Times, 1 September, p. A7.

Government of Rwanda (2000). 'Rwanda Vision 2020'. Kigali: Ministry of Finance and Economic Planning.

Hayman, R. (2009). 'Rwanda: Milking the Cow. Creating Policy Space in Spite of Aid Dependence'. In L. Whitfield (ed.), The Politics of Aid: African Strategies for Dealing with Donors. Oxford: Oxford University Press.

Hayman, R. (2010). 'Abandoned Orphan, Wayward Child: The United Kingdom and Belgium in Rwanda since 1994'. Journal of Eastern African Studies, 4(2): 341-60.

Hintjens, H. (2008). 'Post-Genocide Identity Politics in Rwanda'. Ethnicities, Nations and Nationalism, 8(1): 5-41.

Hintjens, H. (2008). 'Rwanda and Burundi'. In G.H. Herb, and D.H. Kaplan (eds), Nations and Nationalism: A Global Historical Overview. Santa Barbara, CA: ABC-CLIO

Holmes, K., D. Ndihokubwayo, and C. Ruvakubusa (2013). 'For State and Citizen: Reforming Revenue Administration in Burundi'. London: Africa Research Institute.

Human Rights Watch (1994). 'Rwanda: A New Catastrophe'. New York: Human Rights Watch.

Ibreck, R. (2013). 'International Constructions of National Memories: The Aims and Effects of Foreign Donors' Support for Genocide Remembrance in Rwanda'. Journal of Intervention and Statebuilding, 7(2): 149-69.

Ingelaere, B. (2011). 'The Ruler's Drum and the People's Shout: Accountability and Representation on Rwanda's Hills. In S. Straus and L. Waldorf (eds), Remaking Rwanda: Statebuilding and Human Rights after Mass Conflict. Madison: University of Wisconsin Press.

International Crisis Group (2006). 'Burundi: Democracy and Peace at Risk'. Africa Report 120. Nairobi and Brussels: International Crisis Group.

International Monetary Fund (IMF) (2011). 'Rwanda: Second Review under the Policy Support Instrument and Request for Modification of Assessment Criteria'. IMF Country Report, 11(164).

Jackson, S. (2006). 'The United Nations Operation in Burundi (ONUB): Political and Strategic Lessons Learned'. Conflict Prevention and Peace Forum, 7.

Lemarchand, R. (1970). Rwanda and Burundi. London: Pall Mall Publishers.

Lemarchand, R. (2008). 'Part II: Rwanda and Burundi: The Genocidal Twins'. The Dynamics of Violence in Central Africa. University of Pennsylvania Press.

Lemarchand, R. (1994). Burundi: Ethnic Conflict and Genocide. Cambridge: Cambridge University Press.

Malkki, L. (1996). Purity and Exile: Violence, Memory and National Cosmology Among Hutu Refugees in Tanzania. Chicago: University of Chicago Press. 
Mamdani, M. (2002). When Victims Become Killers: Colonialism, Nativism, and the Genocide in Rwanda. Princeton: Princeton University Press.

Manning, C. (2004). 'Armed Opposition Groups into Political Parties: Comparing Bosnia, Kosovo and Mozambique'. Studies in Comparative International Development, 39(1): 54-77.

Marriage, Z. (2006). 'Defining Morality: DFID and the Great Lakes'. Third World Quarterly, 27(3): 477-90.

Marysse, S., A. Ansoms, and D. Cassimon (2007). 'The Aid Darlings and Orphans of the Great Lakes Region of Africa'. European Journal of Development Research, 19(3): 433-58.

McDonough, D. (2008). 'From Guerillas to Government: Post-conflict Stability in Liberia, Uganda and Rwanda'. Third World Quarterly, 29(2): 357-64.

Murigande, C. (2008). 'The Rwandan Genocide - Ten Years On'. Whitehall Papers, 62(1): 3-7.

Museveni, Y. (1997). Sowing the Mustard Seed. London: St Martin's Press.

Ndikumana, L. (2005). 'Distributional Conflict, the State and Peace Building in Burundi'. The Roundtable, 94(381): 413-27.

Newbury, C. (1992). 'Rwanda: Recent Debates over Governance and Rural Development'. In G. Hyden and M. Bratton (eds), Governance and Politics in Africa. Boulder: Lynne Rienner Publishers.

Newbury, C. (2011). 'High Modernism at the Ground Level'. In S. Straus and L. Waldorf (eds), Remaking Rwanda: State-building and Human Rights after Mass Conflict. Madison: University of Wisconsin Press.

Nganou, J.P., and E. Kebede (2012). 'Sources of Growth in Post-Conflict Burundi: From Destruction to Production'. World Bank Policy Research Working Paper. Washington, DC: World Bank.

Nindorera, W. (2012). 'The CNDD-FDD in Burundi: The Path from Armed to Political Struggle'. Berghof Transitions Series No. 10. Berlin: Berghof Foundation.

Nkurunziza, J.D. (2010). 'Why is the Financial Sector in Burundi not Development Oriented?' EUI Working Paper RSCAS 2010/29. Florence: European Union Institute.

Nkurunziza, J., L. Ndikumana, and P. Nyamoya (2012). 'The Financial Sector in Burundi'. National Bureau of Economic Research Working Paper Series, Working Paper 18289. Cambridge MA: NBER.

Otunnu, O. (1999). 'An Historical Analysis of the Invasion by the Rwanda Patriotic Army (RPA)'. In H. Adelman and A. Suhrke (eds). In the Path of Genocide: The Rwanda Crisis from Uganda to Zaire. Transaction Publishers.

Pottier, J. (2002). Re-Imagining Rwanda: Conflict, Survival and Disinformation in the Late Twentieth Century. Cambridge: Cambridge University Press.

Prunier, G. (1998). 'The Rwandan Patriotic Front'. In C. Clapham (ed.), African Guerrillas. Bloomington: Indiana University Press.

Qian, N. (2014). 'Making Progress on Foreign Aid'. Annual Review of Economics, 3, Doi:10.1146/annurev-economics-080614-115553.

Reno, W. (2011). Warfare in Independent Africa. Cambridge: Cambridge University Press.

Reyntjens, F. (2011). 'Constructing the Truth, Dealing with Dissent, Domesticating the World: Governance in Post-Genocide Rwanda'. African Affairs, 110(438): 1-34.

Scherrer, C.P. (2002). Genocide and Crisis in Central Africa: Conflict Roots, Mass Violence and Regional War. Westport, CT: Praeger Publishers. 
Schraeder, P.J., S.W. Hook, and B. Taylor (1998). 'Clarifying the Aid Puzzle: A Comparison of American, Japanese, French, and Swedish Aid Flows'. World Politics, 50: 294-323.

Storey, A. (2001). 'Structural Adjustment, State Power and Genocide: The World Bank and Rwanda'. Review of African Political Economy, 28(89): 365-85.

Straus, S., and L. Waldorf (2011). 'Introduction: Seeing like a Post-Conflict State'. In S. Straus and L. Waldorf (eds), Remaking Rwanda: State-building and Human Rights after Mass Conflict. Madison: University of Wisconsin Press.

Thomson, S. (2011). 'Whispering Truth to Power: The Everyday Resistance of Rwandan Peasants to Post-Genocide Reconciliation'. African Affairs, 110(440): 439-56.

Turner, S. (2013). 'Mirror Images: Different Paths to Building Peace in Rwanda and Burundi'. DIIS Report 22. PLACE: Copenhagen: Danish Institute for International Studies.

United Nations Development Programme (UNDP) (2007). 'Turning Vision 2020 into Reality: From Recovery to Sustainable Human Development'. New York: UNDP.

United Nations Development Programme (UNDP) (2011). 'Human Development Report 2011: Sustainability and Equity: A Better Future for All'. New York: UNDP.

Uvin, P. (1998). Aiding Violence: The Development Enterprise in Rwanda. Bloomfield CT: Kumarian Press.

Uvin, P. (2010). 'Structural Causes, Development Co-operation and Conflict Prevention in Burundi and Rwanda'. Conflict, Security and Development, 10(1): 161-79.

Uvin, P., and L. Bayer (2013). 'The Political Economy of Statebuilding in Burundi'. In M. Berdal and D. Zaum (eds), Political Economy of Statebuilding: Power after Peace. Abingdon: Routledge.

Vandeginste, S. (2011). 'Power-sharing as a Fragile Safety Valve in Times of Electoral Turmoil: The Costs and Benefits of Burundi's 2010 Elections'. Journal of Modern African Studies, 49(2): 315-35.

Vandeginste, S. (2014). 'Governing Ethnicity After Genocide: Ethnic Amnesia in Rwanda versus Ethnic Power-sharing in Burundi'. Journal of Eastern African Studies, 8(2): 263-77.

Verwimp, P., and O. D'Aoust (2013). 'Risk, Security and Coping Mechanisms in Contexts of Violent Conflict: Evidence from Rwanda and Burundi'. In P. Justino, T. Bruck and P. Verwimp (eds), A Micro-Level Perspective on the Dynamics of Conflict, Violence and Development. Oxford: Oxford University Press.

Waldorf, L. (2009). 'Revisiting Hotel Rwanda: Genocide Ideology, Reconciliation and Rescuers'. Journal of Genocide Research, 2(1): 101-25.

Wallis, A. (2006). Silent Accomplice: The Untold Story of France's Role in the Rwandan Genocide. London: I.B. Tauris.

Weinstein, J. (2007). Inside Rebellion: The Politics of Insurgent Violence. Cambridge: Cambridge University Press.

Whitfield, L. (ed.) (2009). The Politics of Aid: African Strategies for Dealing with Donors. Oxford: Oxford University Press.

World Bank (2010). 'Doing Business 2010: Reforming through Difficult Times'. Washington, DC: World Bank.

Zorbas, E. (2011). 'Aid Dependence and Policy Independence: Explaining the Rwandan Paradox'. In S. Straus and L. Waldorf (eds), Remaking Rwanda: State-building and Human Rights after Mass Conflict. Madison: University of Wisconsin Press. 